\title{
The anticonvulsant effects of Ducrosia anethifolia (Boiss) essential oil are produced by its main component alpha-pinene in rats
}

\author{
Os efeitos anticonvulsivantes do óleo essencial de Ducrosia anethifolia (Boiss) são \\ realizados pelo seu principal componente alfa-pineno em ratos \\ Mahnaz Zamyad', Mehdi Abbasnejad', Saeed Esmaeili-Mahani', Ali Mostafavi², Vahid Sheibani
}

\begin{abstract}
Ducrosia anethifolia has been recommended as a remedy for neurological disorders. However, the anticonvulsant effects of D. anethifolia essential oil (DAEO) and its major constituent $\alpha$-pinene have not yet been clarified. Methods: A rat model of pentylenetetrazole (PTZ)induced convulsions was used. Oxidant and antioxidant parameters were assayed in the temporal lobe. Results: The data showed that DAEO (50, 100 and $200 \mathrm{mg} / \mathrm{kg}$, i.p.) and $\alpha$-pinene $(0.2$ and $0.4 \mathrm{mg} / \mathrm{kg}$ i.p.) delayed the initiation time, and reduced the duration of myoclonic and tonic-clonic seizures following PTZ injection. The PTZ produced oxidative stress so that malondialdehyde and hydrogen peroxide levels were increased and catalase and peroxidase activity decreased. Pretreatment with DAEO and $\alpha$-pinene significantly inhibited the abovementioned enzymatic changes in PTZ-treated animals. Conclusion: The results suggest that $\alpha$-pinene, at least in part, was responsible for the induction of the anticonvulsant and antioxidant effects of DAEO in rats.
\end{abstract}

Keywords: Pentylenetetrazole; seizures; oxidative stress..

\section{RESUMO}

A Ducrosia anethifolia tem sido recomendada como remédio para os distúrbios neurológicos. No entanto, os efeitos anticonvulsivantes do óleo essencial de Ducrosia anethifolia (DAEO) e do seu principal constituinte alfa-pineno ( $\alpha$-pineno) ainda não foram clarificados. Métodos: Foi utilizado um modelo de rato de convulsões induzidas por pentilenotetrazol (PTZ). Os parâmetros oxidante e antioxidante foram ensaiados no lobo temporal do cérebro. Resultados: Os dados mostraram que DAEO (50, 100 e 200 mg / kg, i.p.) e $\alpha$-pineno (0,2 e 0,4 mg / kg i.p.) retardaram o tempo de iniciação e reduziram a duração das crises mioclônicas e tônico-clônicas após a injeção de PTZ. O PTZ produziu estresse oxidativo, de modo que os níveis de malondialdeído (MDA) e de peróxido de hidrogênio aumentaram e a atividade da catalase e da peroxidase diminuiu. 0 pré-tratamento com DAEO e $\alpha$-pineno inibiu significativamente as alterações enzimáticas mencionadas em animais tratados com PTZ. Conclusão: 0 resultado sugere que $\alpha$-pineno, pelo menos em parte, é responsável pela indução dos efeitos anticonvulsivantes e antioxidantes da DAEO em ratos.

Palavras-chave: Ducrosia anethifolia; $\alpha$-pinene; Pentilenotetrazol; Crise; Estresse oxidativo.

Epilepsy is one of the oldest conditions known to man and is the third most common neurological disorder after stroke and Alzheimer's disease. Approximately 1\% of the world's population suffers from epilepsy ${ }^{1}$. Anti-epileptic drugs are usually the first choice of treatment for epilepsy but approximately one-third of people with epilepsy do not respond to the drugs. Anti-epileptic drugs do not cure epilepsy, but can prevent seizures from occurring. Recently, it has been proposed that seizures and status epilepticus may be associated with oxidative stress ${ }^{2}$. Oxidative stress, due to the increase in the activity of glutamatergic transmitters, plays a crucial role in the induction of neuronal cell death ${ }^{3}$. Since the brain utilizes the greatest amount of oxygen compared with other organs, it is particularly at risk of oxidative stress ${ }^{4}$.

Experimental models of epilepsy have been developed to find the basic mechanisms of epileptic seizures and new therapeutic approaches. The chemical kindling

\footnotetext{
Shahid Bahonar University of Kerman, Faculty of Sciences, Department of Biology, Kerman, Iran;

${ }^{2}$ Shahid Bahonar University of Kerman, Faculty of Sciences, Department of Chemistry, Kerman, Iran;

${ }^{3}$ Kerman University of Medical Sciences, Kerman Neuroscience Research Center (KNRC), Laboratory of Molecular Neuroscience, Kerman, Iran.

Mehdi Abbasnejad (iD) https://orcid.org/0000-0001-6024-4507

Correspondence: Mehdi Abbasnejad; Dept. of Biology, Faculty of Sciences, Shahid Bahonar University of Kerman, Kerman, Iran; P.0.Box: 76135-133; E-mail: mabbas@uk.ac.ir

Conflict of interest: There is no conflict of interest to declare.
}

Support: Shahid Bahonar University and Kerman Neuroscience Research Center (KNRC/94).

Received 29 November 2017; Received in final form 28 September 2018; Accepted 16 October 2018. 
induced by the pentylenetetrazole (PTZ) is one of the most-widely used models for the induction of convulsions in animals.

Medicinal plants have recently become a major target in the search for new drugs and have led to compounds to treat epilepsy accompanied by oxidative stress ${ }^{5,6}$. Ducrosia anethifolia Boiss, known in Persian as Moshgak, Roshgak, and Moshkbu, belongs to the Apiaceae family. It is one of the three species of Iranian Ducrosia growing wild in southeastern Iran, in the mountainous regions of the Kerman province ${ }^{7}$. In Iranian traditional Medicine, the whole herb-especially its aerial parts-has been used as an analgesic for headache, backache, as well as for the treatment of colic, and colds. It is also used to relax the body and mind, allowing a restful sleep ${ }^{8}$. Furthermore, antianxiolytic effects of $D$. anethifolia essential oil (DAEO) have been reported ${ }^{9}$. The antioxidant, antimicrobial, antimycobacterial, antifungal, and central nervous system depressant effects of this plant and other species of Ducrosia have been reported in pharmacological and biological studies ${ }^{10}$. Phytochemical studies of DAEO revealed that aliphatic aldehydes and other monoterpene hydrocarbons such as limonene, citronellal, terpinolene, myrcene, $\alpha$-pinene, pulegone, $p$-cymene and coumarins such as pangelin are the main components of $D$. anethifolia aerial parts ${ }^{11}$. High performance liquid chromatography (HPLC) analysis of DAEO indicated the presence of terpenoids such as $\alpha$-pinene as one of the major components. Terpenes constitute the major portion of the essential oils and, somehow, are responsible for the medicinal plant's pharmacological activities such as antinociceptive, anti-inflammatory and anticonvulsant effects ${ }^{12}$.

It has been reported that $\alpha$-pinene has anticonvulsant and antioxidant properties ${ }^{13}$. However, there is no scientific information to validate the anticonvulsant activity of this plant in experimental animals. Therefore, the present study was designed to determine the possible effects of DAEO, and its major component $\alpha$-pinene, on PTZ-induced seizure and brain oxidative stress in male rats.

\section{METHODS}

\section{Animals}

Adult male Wistar rats weighting 200-250g were prepared from the Animal House of Shahid Bahonar University of Kerman. The animals were housed in a room with photoperiod control (a 12-hour light/dark cycle) and temperature $\left(22 \pm 2^{\circ} \mathrm{C}\right)$. Food and water was available $a d$ libitum. All experimental procedures were approved by the Animal Research Ethics Committee of the Kerman Neuroscience Research Center, Kerman, Iran (EC/95).

\section{Drugs}

Pentylenetetrazole, $\alpha$-pinene and diazepam were purchased from Sigma-Aldrich Co. The drugs were dissolved in a saline solution (0.9\%) and injected intraperitoneally (i.p.) in a volume of $1 \mathrm{ml} / \mathrm{kg}$ of the rat's body weight.

\section{Plant material}

Fresh aerial parts (leaves and flowers) of D. anethifolia were collected, in July, from the Lalehzar mountainous area in Kerman province, Iran, at an altitude of 2,800 m. The voucher specimens were deposited at the herbarium of Shahid Bahonar University of Kerman (Code number: 1371). The material was dried at room temperature and used for distillation. The essential oil was isolated by hydrodistillation of the fresh aerial parts for 4 hours, and then dried over anhydrous sodium sulfate 14 and stored in a refrigerator $\left(4^{\circ} \mathrm{C}\right)$.

\section{Acute toxicity}

Seven rats were treated with the DAEO (500 mg/kg, i.p.) and the mortality and morbidity were determined.

\section{PTZ-induced seizures}

Pentylenetetrazole ( $80 \mathrm{mg} / \mathrm{kg}$, i.p.) was injected to induce convulsions in rats. Diazepam $(2 \mathrm{mg} / \mathrm{kg}$, i.p. $)$ and DAEO (25, 50, 100 and $200 \mathrm{mg} / \mathrm{kg}$, i.p.) and $\alpha$-pinene (0.2 and $0.4 \mathrm{mg} / \mathrm{kg}$, i.p.) were administered 30 minutes before receiving PTZ. The seizure parameters were precisely monitored for 40 minutes after each PTZ injection in all groups. The following parameters were measured using a stopwatch in seconds, and behaviors were recorded with a CD camera.

The resultant seizures were classified according to the modified Racine scale ${ }^{14}$ as follows:

Stage 0: no response.

Stage 1: ear and facial twitching.

Stage 2: myoclonic jerks without rearing.

Stage 3: myoclonic jerks, rearing.

Stage 4: turning over onto side position, tonic-clonic seizures.

Stage 5: turning over onto back position, generalized tonic-clonic seizures.

1) Latency: the time between PTZ injection and the onset of seizures ${ }^{15}$.

2) Duration: the time interval from the onset to termination of seizures or death of the animal.

3) Percent of death: the number of rats that died after PTZ injection among the rats of a particular group.

4) Protection percentage: the number of rats that responded to the test ${ }^{16}$. $\mathrm{P} \%=1-(\mathrm{nt} / \mathrm{Nt})(\mathrm{nc} / \mathrm{NC}) \times 100$.

\section{Biochemical measurements}

After behavioral assessment, the animals were euthanized under deep anesthesia, and the temporal lobes of the brains were dissected and stored at $-80^{\circ} \mathrm{C}$ until the day of assay. 


\section{Brain lipid peroxidation}

Lipid peroxidation products such as malondialdehyde (MDA) are considered to be reliable indicators of oxidative damage ${ }^{17}$. Temporal lobe tissue $(0.5 \mathrm{~g})$ was homogenized in $10 \mathrm{mg}$ of $0.1 \%$ trichloroacetic acid; the homogenate was centrifuged at 15,000 rpm for 15 minutes to $1.0 \mathrm{mg}$ aliquot of the supernatant; and $4.0 \mathrm{mg}$ of $0.5 \%$ thiobarbituric acid in $20 \%$ trichloroacetic acid was added. The mixture was heated at $95^{\circ} \mathrm{C}$ for 30 minutes and then cooled in an ice bath. After centrifugation $(10,000 \mathrm{rpm}$ for 10 minutes), the absorbance of the supernatant was recorded at $532 \mathrm{~nm}$ (Biochrom WPA Biowave II UV/Visible Spectrophotometer). The thiobarbituric acid reactive substances content was calculated according to its extinction coefficient of $155 \mathrm{mM}^{-1} \mathrm{~cm}^{-1}$ and expressed in units (U). One ' $U$ ' is defined as $\mu \mathrm{mol}$ of MDA formed $\mathrm{min}^{-1} \mathrm{mg}^{-1}$ protein.

\section{Hydrogen peroxide}

Hydrogen peroxide $\left(\mathrm{H}_{2} \mathrm{O}_{2}\right)$ was determined by the method described by Velikova et al., (2000). Temporal lobe tissue $(0.5 \mathrm{~g})$ was finely ground with trichloroacetic acid $(5 \mathrm{ml}$ of $0.1 \% \mathrm{w} / \mathrm{v})$ and centrifuged at $10,000 \times g$ for 15 minutes. Phosphate buffer $(0.5 \mathrm{ml}, \mathrm{pH} 7.0)$ and $1 \mathrm{ml}$ potassium iodide were added to the $0.5 \mathrm{ml}$ supernatant. Its absorbance was recorded at $390 \mathrm{~nm}$ after overtaxing using a UV visible spectrophotometer.

\section{Total soluble proteins}

Total proteins were estimated using the Bradford method and bovine serum albumin was used as the standard.

\section{Antioxidant enzymes activities}

Temporal lobe tissue $(0.5 \mathrm{~g})$ was finely ground under chilled conditions in $3 \mathrm{ml}$ of phosphate buffer $(50 \mathrm{mM}$ with $\mathrm{pH}$ 7.5) for the extraction of antioxidant enzymes. Centrifugation of the mixture was performed at $10,000 \times g$ for 10 minutes at $4^{\circ} \mathrm{C}$. The supernatant was recentrifuged at $15,000 \times g$ for 10 minutes and the resultant extract stored at $-20^{\circ} \mathrm{C}$ for determination of the activity of antioxidant enzymes.

\section{Evaluation of catalase activity}

The activity of catalase (CAT) was estimated by monitoring the decrease in absorbance of $\mathrm{H}_{2} \mathrm{O}_{2}$ within 30 seconds at $240 \mathrm{~nm}$. The assay solution contained $50 \mathrm{mM}$ potassium phosphate buffer ( $\mathrm{pH} 7.0)$ and $15 \mathrm{mM} \mathrm{H}_{2} \mathrm{O}_{2}$ and $100 \mu \mathrm{l}$ enzyme extract ${ }^{18}$.

\section{Evaluation of peroxidase activity}

Peroxidase (POD) activity was assayed according to the method of Plewa et al. ${ }^{19}$, based on the amount of tetraguaiacol absorbed after formation, by oxidation, of guaiacol catalyzed by this enzyme in 3 minutes at a wavelength of 470 $\mathrm{nm}$ using an extinction coefficient of tetraguaiacol, $\varepsilon=26.6$ $\mathrm{mM}^{-1} \mathrm{~cm}^{-1}$.

\section{HPLC analysis}

The obtained essential oil was analyzed using HPLC (Agilent Technologies, 1200 Infinity series, USA) equipped with a 1260 Infinity Quaternary Pump and a 1260 Infinity Variable Wavelength Detector. An Agilent 1260 Infinity Manual Injector fitted with a $20 \mu \mathrm{L}$ sample loop was used to introduce the samples. The analytes were separated on a Restek Ultra C18 (250 mm × $4.6 \mathrm{~mm}, 5 \mu \mathrm{m})$ column (USA). Chromatograms were processed by an Agilent HPLC Chem Station (Rev. B.04.03).

\section{Statistical analysis}

The data are expressed as mean \pm SEM. Comparison between groups was made by analysis of variance followed by the Tukey test. Differences between experimental groups of each point with $\mathrm{p}<0.05$ were considered statistically significant.

\section{RESULTS}

\section{Acute toxicity}

The essential oil of $D$. anethifolia has shown no mortality up to a dose of $500 \mathrm{mg} / \mathrm{kg}$. However, we used doses of 25, 50, 100 and $200 \mathrm{mg} / \mathrm{kg}$ in this study.

\section{Anticonvulsant activity assessment}

\section{Effect of DAEO on PTZ-induced seizures}

The essential oil showed dose-dependent effects against PTZ-induced seizures. Itcould significantlyreducethenumber of convulsing animals. Pretreatment with DAEO (50, 100 and $200 \mathrm{mg} / \mathrm{kg}$ ) and $\alpha$-pinene $(0.2$ and $0.4 \mathrm{mg} / \mathrm{kg}$ ) significantly reduced mortality rate and attenuated PTZ-induced seizures (Table).

\section{Effect of DAEO and $a$-pinene on the onset of seizure}

The DAEO (50, 100 and $200 \mathrm{mg} / \mathrm{kg}$, i.p.) significantly delayed the onset of PTZ-induced seizures. However, diazepam and $\alpha$-pinene had no significant effects on the onset of seizure (Figure 1).

\section{Effect of DAEO and a-pinene on the duration of seizure}

The essential oil at doses of 50, 100 and $200 \mathrm{mg} /$ $\mathrm{kg}$, $\alpha$-pinene $(0.2$ and $0.4 \mathrm{mg} / \mathrm{kg})$ and diazepam could significantly alter the duration of seizures in PTZ-treated rats. However, $25 \mathrm{mg} / \mathrm{kg}$ of DAEO had no effect on the duration of seizures (Figure 2). 
Table. The effect of Ducrosia anethifolia essential oil and $\alpha$-pinene on pentylenetetrazole (PTZ) induced seizures in rats.

\begin{tabular}{|c|c|c|c|c|c|}
\hline \multirow{2}{*}{ Treatment and doses (mg/kg, i.p) } & \multicolumn{3}{|c|}{ Duration of seizure (sec.) } & \multirow{2}{*}{ \% Mortality } & \multirow{2}{*}{$\%$ Protection } \\
\hline & Myoclonic & Tonic & Tonic-clonic & & \\
\hline PTZ & $34 \pm 03$ & $31 \pm 42$ & $165 \pm 86$ & 100 & 14 \\
\hline $\begin{array}{l}\text { PTZ + Diazepam } \\
2 \mathrm{mg} / \mathrm{kg}\end{array}$ & $2 \pm 14^{\star \star \star}$ & $4 \pm 85^{\star \star \star *}$ & $4 \pm 14^{\star * *}$ & 0 & 100 \\
\hline $\begin{array}{l}\text { PTZ + D. anethifolia } \\
25 \mathrm{mg} / \mathrm{kg}\end{array}$ & $20 \pm 01$ & $40 \pm 01$ & $162 \pm 71$ & 71 & 29 \\
\hline $\begin{array}{l}\text { PTZ + D. anethifolia } \\
50 \mathrm{mg} / \mathrm{kg}\end{array}$ & $10 \pm 42 \star \star$ & $13 \pm 57 \star$ & $13 \pm 42 * \star \star$ & 0 & 100 \\
\hline $\begin{array}{l}\text { PTZ + D. anethifolia } \\
100 \mathrm{mg} / \mathrm{kg}\end{array}$ & $13 \pm 71 * \star$ & $18 \pm 14$ & $35 \pm 57 * \star \star$ & 14 & 86 \\
\hline $\begin{array}{l}\mathrm{PTZ}+\text { D. anethifolia } \\
200 \mathrm{mg} / \mathrm{kg}\end{array}$ & $17 \pm 42 *$ & $19 \pm 14$ & $27 \pm 14^{\star \star \star}$ & 14 & 86 \\
\hline $\begin{array}{l}\mathrm{PTZ}+\alpha \text {-pinene } \\
0.2 \mathrm{mg} / \mathrm{kg}\end{array}$ & $16 \pm 71^{*}$ & $10 \pm 57 \star \star$ & $31 \pm 57 * * *$ & 42 & 58 \\
\hline $\begin{array}{l}\text { PTZ }+\alpha \text {-pinene } \\
0.4 \mathrm{mg} / \mathrm{kg}\end{array}$ & $13 \pm 43^{\star *}$ & $8 \pm 42 \star \star$ & $21 \pm 71 * * *$ & 28 & 72 \\
\hline
\end{tabular}

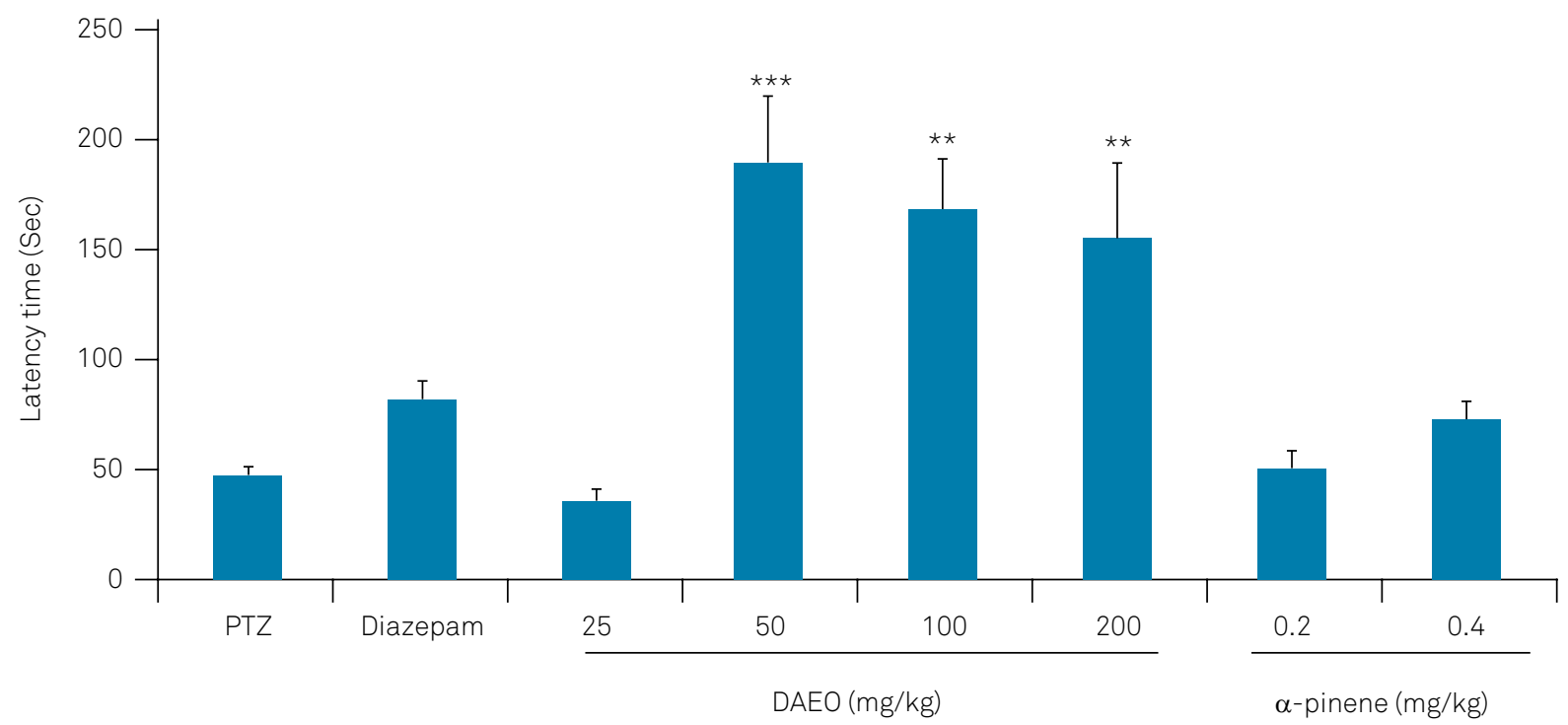

Histograms represent mean \pm SEM for seven animals. ${ }^{* \star} \mathrm{p}<0.001,{ }^{* \star} \mathrm{p}<0.01$, versus PTZ group by analysis of variance with Tukey's post hoc test. Figure 1. The effect of Ducrosia anethifolia essential oil (DAEO) and $\alpha$-pinene on the onset of seizure of pentylenetetrazole (PTZ)-induced convulsion in rats.

\section{Biochemical measurements}

\section{MDA levels}

The PTZ injection significantly increased brain temporal lobe MDA levels, which were significantly attenuated by DAEO $(50,100,200 \mathrm{mg} / \mathrm{kg})$ and $\alpha$-pinene (0.2 and $0.4 \mathrm{mg} / \mathrm{kg}$ ) (Figure 3).

\section{$\mathrm{H}_{2} \mathrm{O}_{2}$ levels}

The PTZ-treated rats showed a significant increase in $\mathrm{H}_{2} \mathrm{O}_{2}$ levels in the temporal lobe. Alternatively, DAEO, $\alpha$-pinene and diazepam significantly decreased PTZ-induced $\mathrm{H}_{2} \mathrm{O}_{2}$ production (Figure 4).

\section{The effect of DAEO and $\alpha$-pinene on brain CAT and $P O D$ activities in PTZ-treated animals}

The brain CAT and POD activities were significantly decreased following PTZ administration. However, DAEO (50,100 and $200 \mathrm{mg} / \mathrm{kg}), \alpha$-pinene $(0.2$ and $0.4 \mathrm{mg} / \mathrm{kg})$ and diazepam could prevent the effect of PTZ on CAT and POD activities (Figure 5 and 6).

\section{HPLC analysis}

According to the obtained HPLC spectrum of essential oil of D. anethifolia, there was a major peak following retention times (min): 6.950 (Figure 7). The peak for the reference standard, $\alpha$-pinene, appeared at the retention time ( $\mathrm{min}$ ) of 6.866 . 


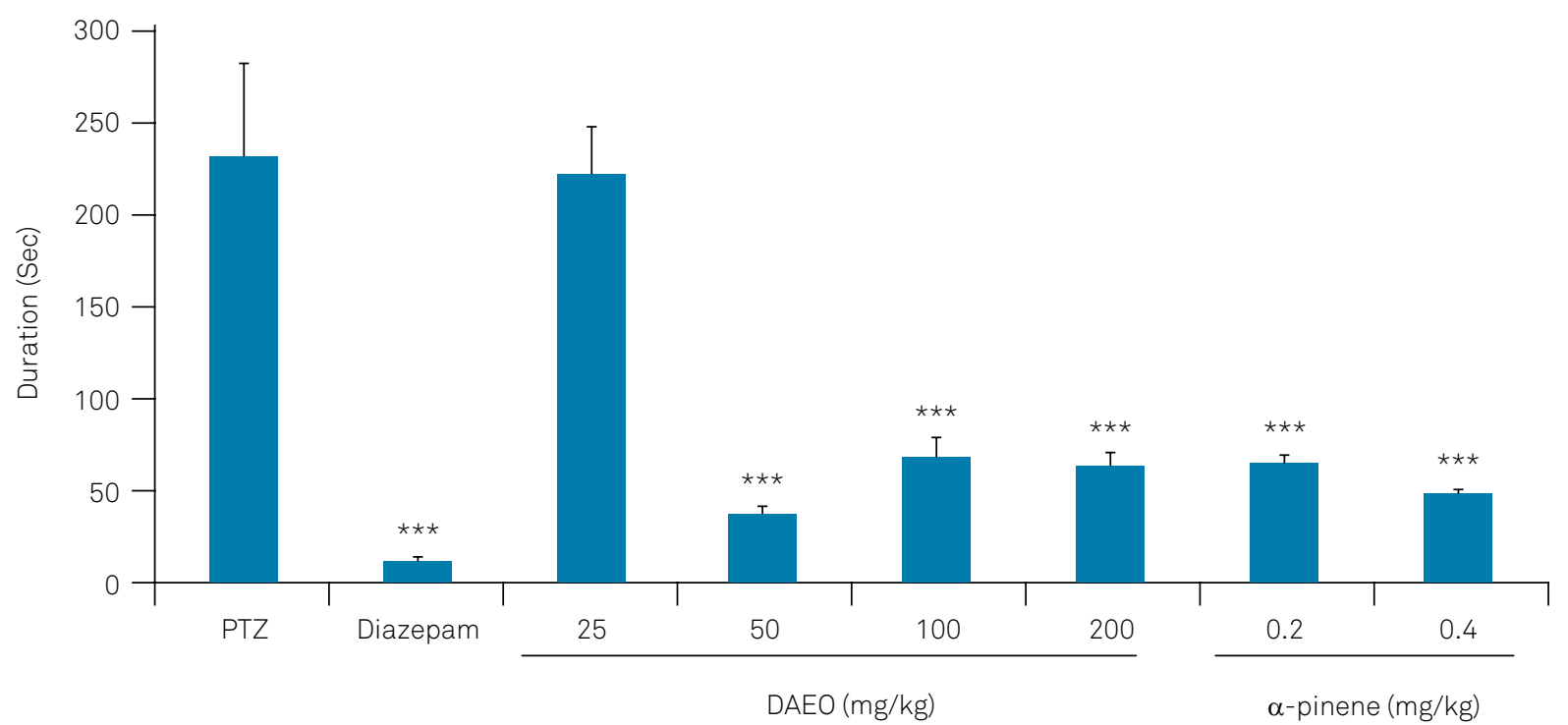

Histograms represent mean \pm SEM $(n=7)$. $* * \star * p<0.001$ versus PTZ-treated group. The data were analyzed by one-way analysis of variance with Tukey's post hoc test.

Figure 2. The effect of Ducrosia anethifolia essential oil (DAEO) and $\alpha$-pinene on the duration of PTZ-induced seizure in Rats.

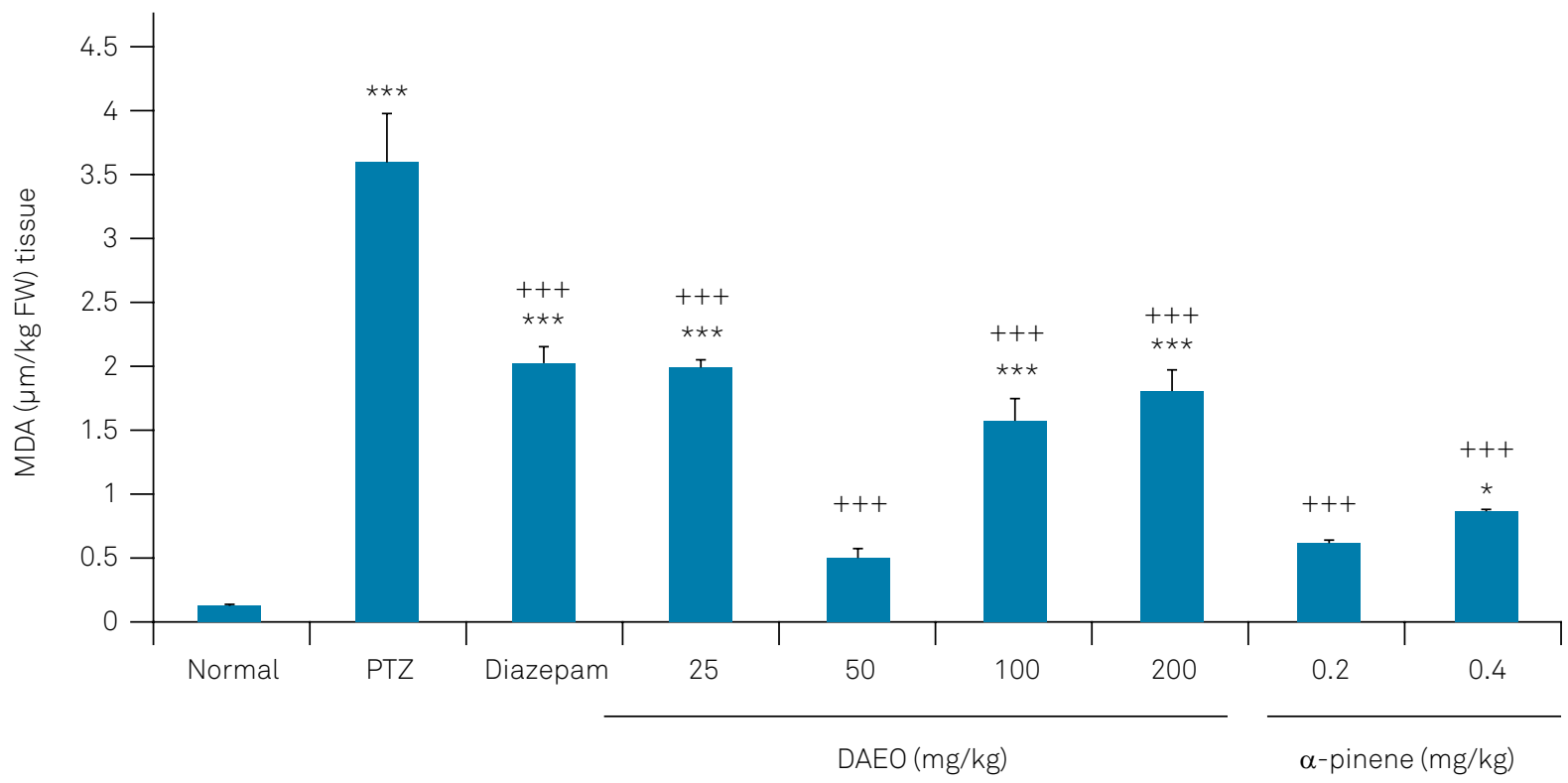

Data represent means \pm SEM $(n=7),{ }^{* * *} p<0.001$ and ${ }^{*} p<0.05$ compared with nontreated normal rats. $+++p<0.001$ versus PTZ-injected group. Figure 3. The effect of Ducrosia anethifolia essential oil (DAEO) and $\alpha$-pinene on the temporal lobe MDA levels in the PTZ seizure models.

\section{DISCUSSION}

In the present work, the effects of DAEO and $\alpha$-pinene were studied. Ducrosia anethifolia essential oil and $\alpha$-pinene were initially evaluated in a behavioral study that gave a good indication of the reduction of seizures. Additionally, the results showed that DAEO and $\alpha$-pinene were able to significantly decrease the oxidative stress factors after seizures induced by PTZ.

The PTZ method is a valid model of convulsion for the study of generalized myoclonic (absence) seizures ${ }^{20,21,22}$. It has been demonstrated that oxidative stress resulting from free radicals plays a critical role in the genesis of epilepsy and in post-seizure neuronal death. The brain is particularly susceptible to oxidative stress damage ${ }^{4,23,24}$. Traditionally, medicinal plants with antioxidant properties have been candidates for preventing oxidative damage and epilepsy ${ }^{25}$. The phytochemical and HPLC analysis by Hajhashemi et al. ${ }^{9}$ showed that DAEO had a wide spectrum of bioactive compounds, and terpenoids were its major components'. The antinociceptive, anticonvulsant and anti-inflammatory properties of monoterpenes, such as $\alpha$-pinene, carvacrol, $\gamma$-terpineol, citronellol 


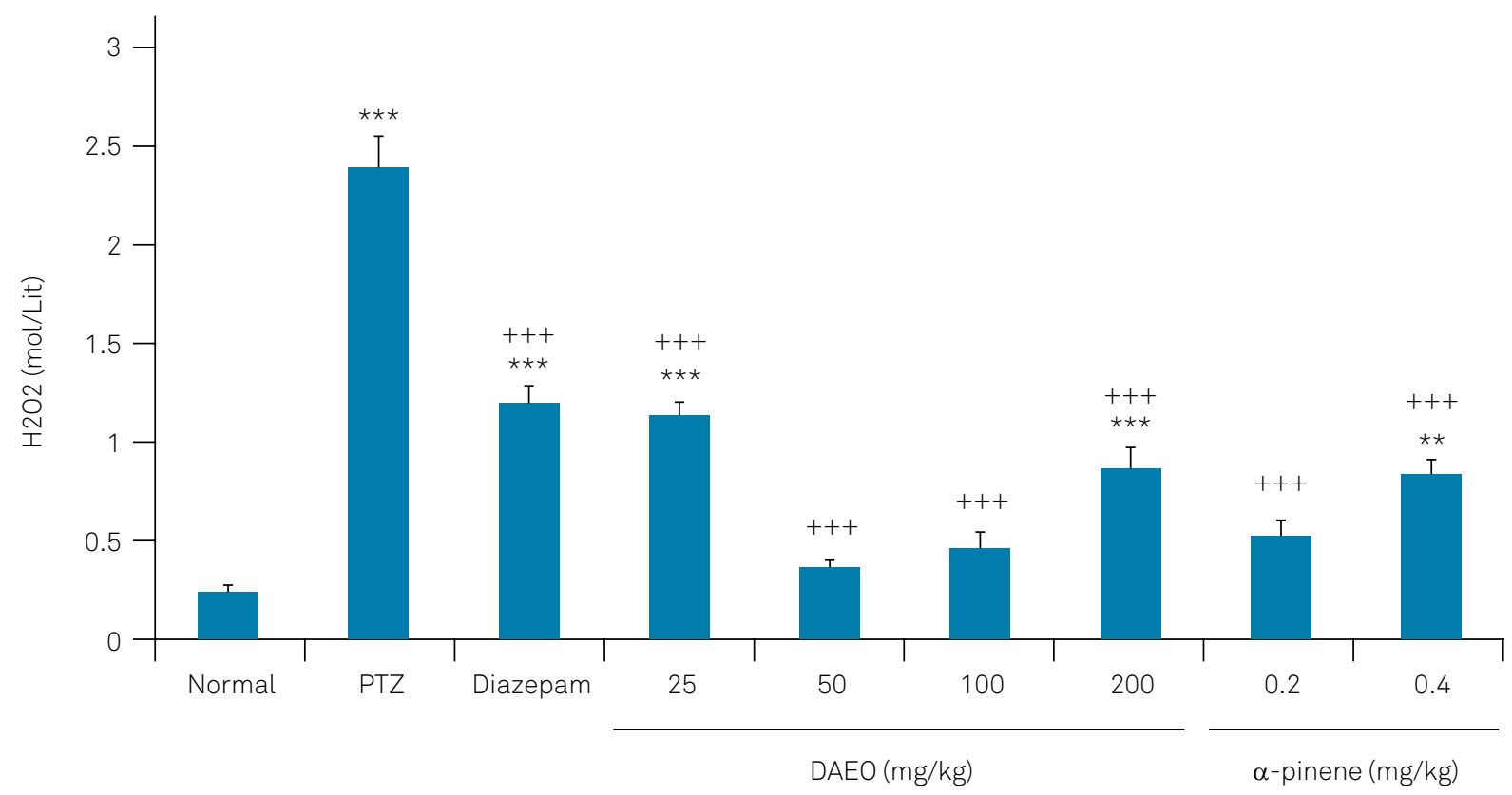

Data represent means \pm SEM $(n=7),{ }^{* * *} p<0.001$ and $* * p<0.01$ compared with the control nontreated groups. $+++p<0.001$ compared with PTZ-treated animals. Figure 4. The effect of Ducrosia anethifolia essential oil (DAEO) and $\alpha$-pinene on the temporal lobe $\mathrm{H}_{2} \mathrm{O}_{2}$ levels in the rat PTZ seizure models.

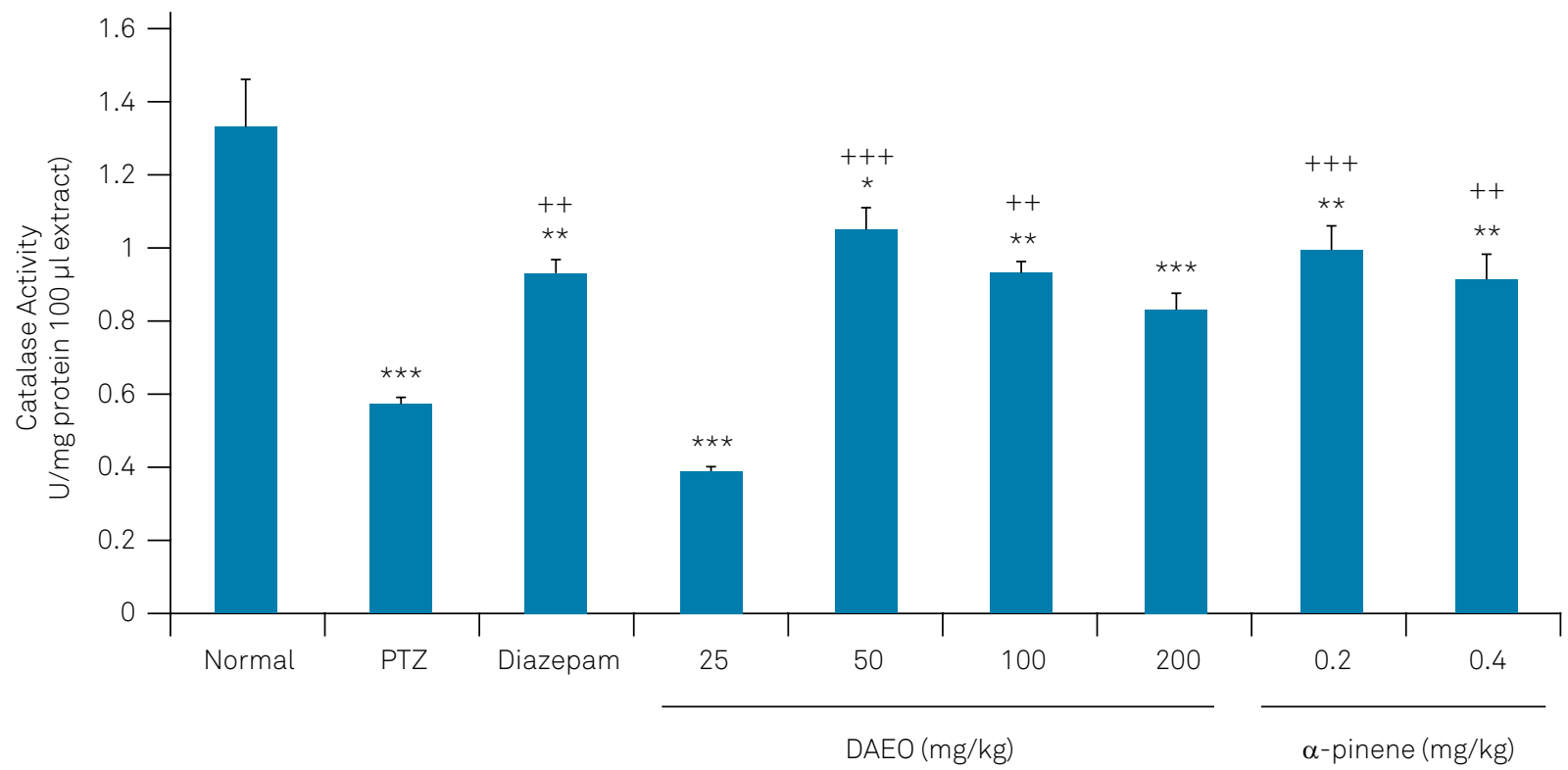

Data represent means \pm SEM $(n=7)$, ${ }^{* * *} p<0.001,{ }^{*} p<0.01$ and ${ }^{*} p<0.05$ compared with the control non-treated groups. $+++p<0.001$ and $++p<0.01$ compared with PTZ-treated animals.

Figure 5. The effect of Ducrosia anethifolia essential oil (DAEO) and $\alpha$-pinene on catalase activity in the temporal lobe of the brain in the PTZ seizure model.

and linalool have been reported ${ }^{26,27}$. Pentylenetetrazole induces convulsion by inhibiting GABA receptors-chloride channel complexes. It appears that the inhibitory effect of DAEO against PTZ-induced seizure may occur through the rise of the convulsion threshold in the brain via the stimulation of GABA receptors ${ }^{28}$. The $\alpha$-pinenes, as major components of DAEO, have a promoting effect on $\mathrm{GABA}_{\mathrm{A}}$ receptors and increase the postsynaptic GABA-dependent chloride flows, as well as being a potent inhibitor of acetylcholinester$a^{13} \mathrm{e}^{13}$. The major inhibitory neurotransmitter in the brain is GABA and the inhibition of its neurotransmission has been thought to be a critical factor in epilepsy ${ }^{29}$. The standard antiepileptic drugs, phenobarbital and diazepam, can induce their antiepileptic effects by enhancing GABA neurotransmission. Glutamate and glutamatergic receptors are located 


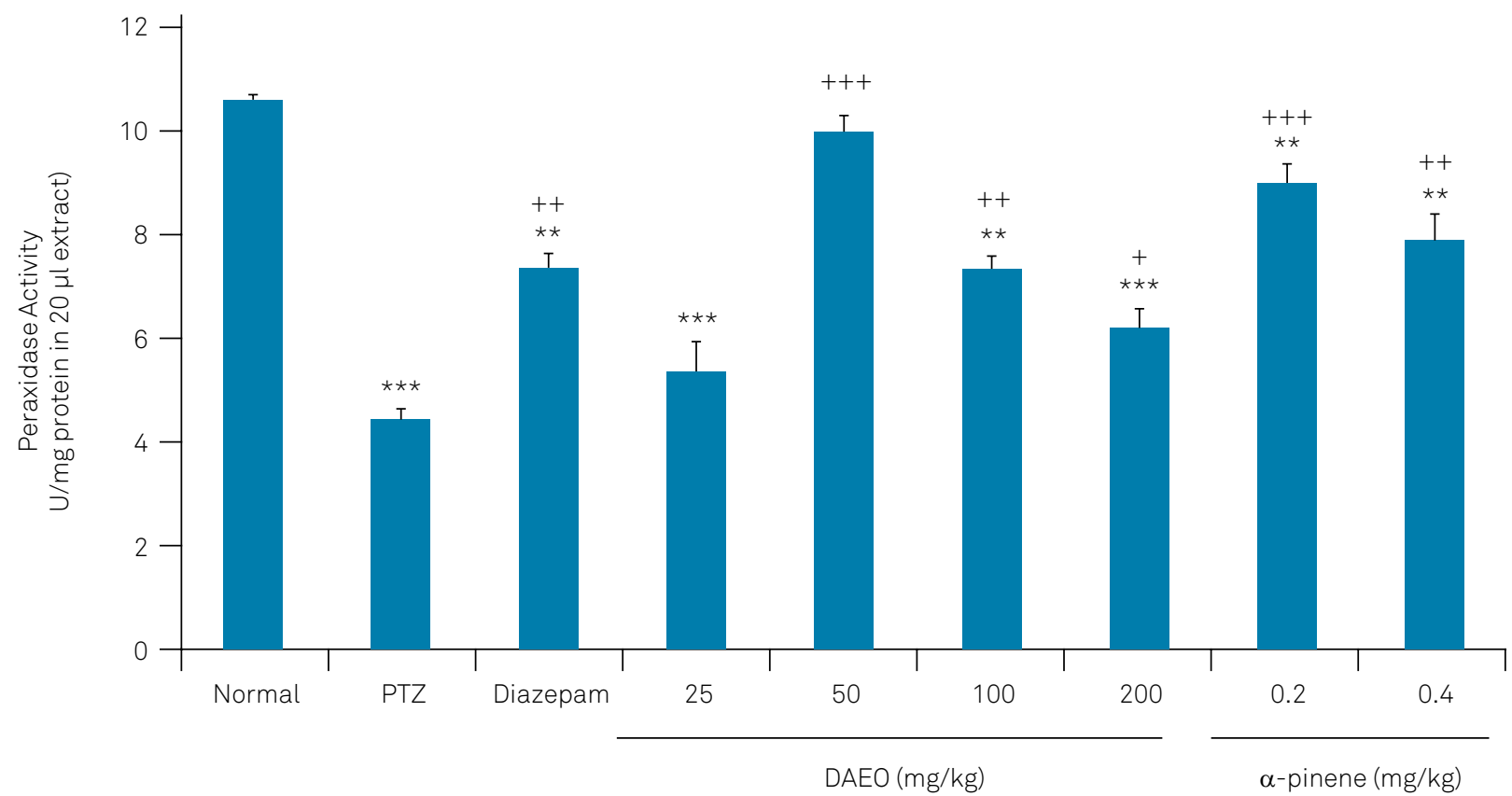

Data represent means \pm SEM $(n=7), * \star \star * p<0.001, * \star p<0.01$ compared with the control untreated groups. $+++p<0.001$ and $++p<0.01$ compared with PTZ-treated animals.

Figure 6. The effect of Ducrosia anethifolia essential oil (DAEO) and $\alpha$-pinene on peroxidase activity in the temporal lobe in the PTZ seizure model.

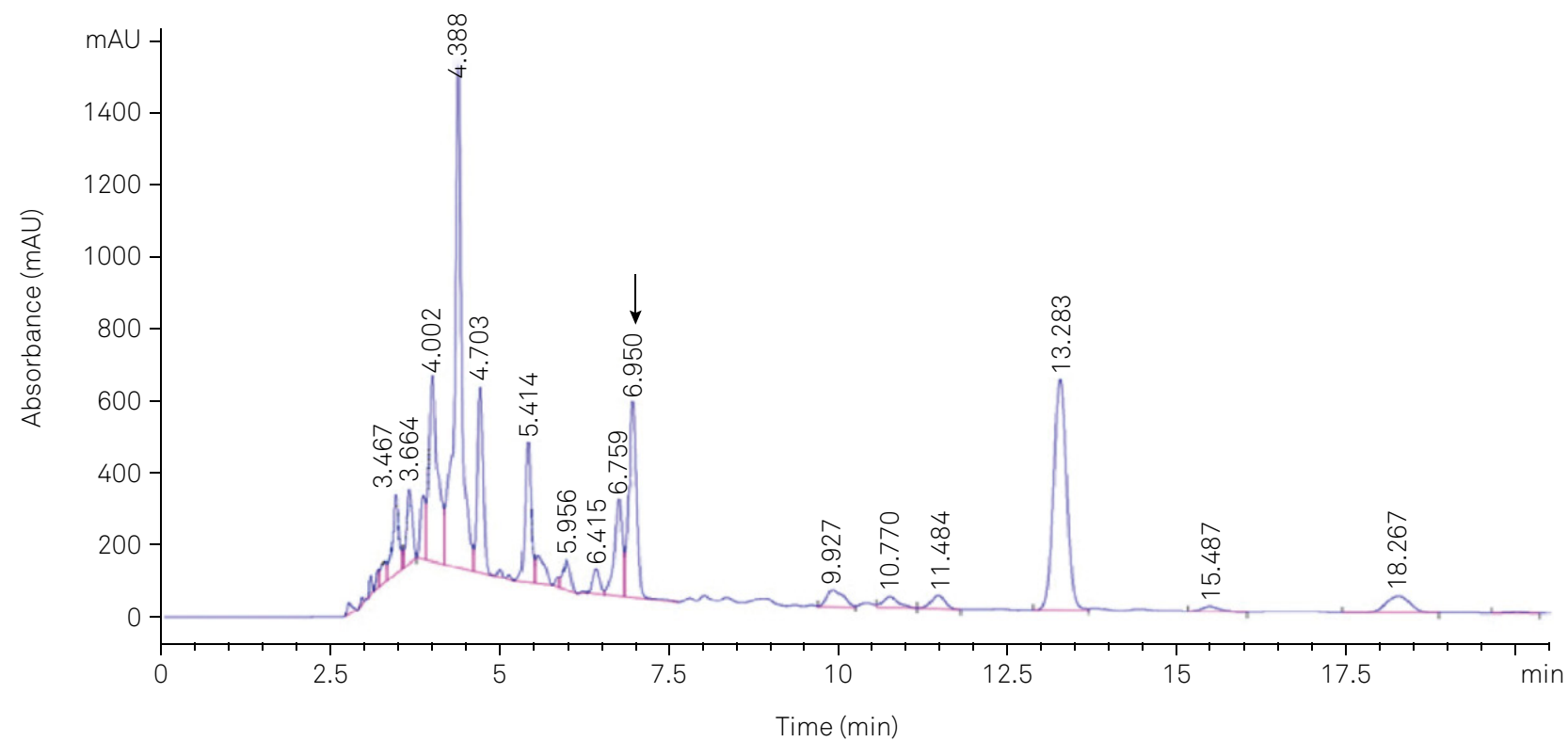

Figure 7. HPLC chromatogram of Ducrosia anethifolia essential oil (DAEO).

in both central and peripheral nervous systems and may be responsible for most of the excitatory neurotransmission.

In addition to GABA dysregulation, it has been indicated that excitatory amino acids are also involved in the initiation and propagation of seizures ${ }^{30,31}$. Citronellal, citronellol, myrcene and $\beta$-pinene, the DAEO monoterpenes, have NMDA receptor antagonist activities and can protect neurons against overstimulation ${ }^{30,32}$. Activation of NMDA receptors generally increases intracellular calcium influx, which raises neuronal excitation and excitability mainly via stimulation of cAMP-dependent signaling molecules including adenylyl cyclases and protein kinase $\mathrm{A}^{33}$. Especially, it has been reported that down-regulation of the cAMP-response element-binding protein is correlated with the suppression of epileptic seizures ${ }^{34}$. It has been reported that linalool, a DAEO constituent compound, exerts a considerable anticonvulsant activity in a rat model of PTZ-kindling via modulation of glutamatergic currents ${ }^{35}$. In addition, 
linalool inhibits adenylate cyclase in chick retinas ${ }^{36}$. Thus, DAEO anticonvulsant capacity, at least in part, is mediated by modulation of intracellular second messengers such as calcium and glutamate. However, additional studies are still required to clarify this important issue in more details.

In the present study, PTZ-induced seizures could increase the levels of oxidative stress indicators such as MDA and $\mathrm{H}_{2} \mathrm{O}_{2}$, and decrease the activities of antioxidant enzymes, CAT and POD $^{37,38}$. It has been demonstrated that the use of free radical scavengers in the treatment of epilepsy provides an important perspective that will be the driving force for future drug design of novel antiepileptics ${ }^{39}$. Pretreatment with DAEO and $\alpha$-pinene could prevent the seizures and thus decrease oxidative stress. The data showed a dose-dependent effect of DAEO against seizure-induced oxidative stress in experimental models of seizures.

Potential antioxidant therapy that includes either natural antioxidants or agents is capable of augmenting the functions of these enzymes ${ }^{40}$. Earlier reports have shown that the natural drugs like DAEO have antioxidant properties because of the presence of $\alpha$-pinene, citronellal, $\gamma$-terpinene, myrcene and limonene $e^{41}$.

Taken together, the data suggest that DAEO and $\alpha$-pinene have antiepileptic activities. This effect may be due to their antioxidant properties and possible activation of $\mathrm{GABA}_{\mathrm{A}}$ receptors. Our experiment contributes to our knowledge of the pharmacology of $D$. anethifolia (Boiss).

\section{References}

1. Löscher W. Current status and future directions in the pharmacotherapy of epilepsy. Trends Pharmacol Sci. 2002 Mar;23(3):113-8. https://doi.org/10.1016/S0165-6147(00)01974-X

2. Barros L, Ferreira MJ, Queiros B, Ferreira IC, Baptista P. Total phenols, ascorbic acid, $\beta$-carotene and lycopene in Portuguese wild edible mushrooms and their antioxidant activities. Food Chem. 2007;103(2):413-9. https://doi.org/10.1016/j.foodchem.2006.07.038

3. Rauca C, Zerbe R, Jantze H. Formation of free hydroxyl radicals after pentylenetetrazol-induced seizure and kindling. Brain Res. 1999 Nov;847(2):347-51. https://doi.org/10.1016/S0006-8993(99)02084-3

4. Mariani E, Polidori MC, Cherubini A, Mecocci P. Oxidative stress in brain aging, neurodegenerative and vascular diseases: an overview. J Chromatogr B Analyt Technol Biomed Life Sci. 2005 Nov;827(1):65-75. https://doi.org/10.1016/j.jchromb.2005.04.023

5. Golechha M, Bhatia J, Ojha S, Arya DS. Hydroalcoholic extract of Emblica officinalis protects against kainic acid-induced status epilepticus in rats: evidence for an antioxidant, anti-inflammatory, and neuroprotective intervention. Pharm Biol. 2011 Nov;49(11):1128-36. https://doi.org/10.3109/13880209.2011.571264

6. Mehla J, Reeta KH, Gupta P, Gupta YK. Protective effect of curcumin against seizures and cognitive impairment in a pentylenetetrazole-kindled epileptic rat model. Life Sci. 2010 Nov;87(19-22):596-603. https://doi.org/10.1016/j.lfs.2010.09.006

7. Mozaffarian V. A dictionary of Iranian plant names: Latin, English, Persian. City: Farhang Mo'aser; 1996.

8. Haghi G, Safaei A, Safari J. Extraction and determination of the main components of the essential oil of Ducrosia anethifolia by GC and GC/MS. Iran J Pharm Res. 2004;3(suppl 2):90-91.

9. Hajhashemi V, Rabbani M, Ghanadi A, Davari E. Evaluation of antianxiety and sedative effects of essential oil of Ducrosia anethifolia in mice. Clinics (São Paulo). 2010;65(10):1037-42. https://doi.org/10.1590/S1807-59322010001000020

10. Stavri M, Mathew KT, Bucar F, Gibbons S. Pangelin, an antimycobacterial coumarin from Ducrosia anethifolia. Planta Med. 2003 Oct;69(10):956-9. https://doi.org/10.1055/s-2003-45109

11. Mostafavi A, Afzali D, Mirtadzadini S. Chemical composition of the essential oil of Ducrosia anethifolia (DC.) Boiss. from Kerman Province in Iran. J Essent Oil Res. 2008;20(6):509-12. https://doi.org/10.1080/10412905.2008.9700073

12. Guilhon CC, Raymundo LJ, Alviano DS, Blank AF, Arrigoni-Blank MF, Matheus ME et al. Characterisation of the anti-inflammatory and antinociceptive activities and the mechanism of the action of Lippia gracilis essential oil.J Ethnopharmacol. 2011 May;135(2):406-13. https://doi.org/10.1016/j.jep.2011.03.032
13. Miyazawa M, Yamafuji C. Inhibition of acetylcholinesterase activity by bicyclic monoterpenoids. J Agric Food Chem. 2005 Mar;53(5):1765-8. https://doi.org/10.1021/jf040019b

14. Racine RJ. Modification of seizure activity by electrical stimulation. II. Motor seizure. Electroencephalogr Clin Neurophysiol. 1972 Mar;32(3):281-94. https://doi.org/10.1016/0013-4694(72)90177-0

15. Akamatsu N, Fueta Y, Endo Y, Tamagawa A, Yuhi T, Uozumi Tet al., editors. The therapeutic effects of high-frequency transcranial magnetic stimulation on pentylenetetrazol-induced status epilepticus in rats. Int Congr Ser. 2005 Mar;1278423-6. https://doi.org/10.1016/j.ics.2004.11.130

16. Abbasnejad M, Keramat B, Mahani E, Rezaeezade-Roukerd M. Effect of hydro-methanolic extract of sour orange flowers, Citrus aurantium, on pentylentetrazole induced seizure in male rats. Majallah-i Danishgah-i Ulum-i Pizishki-i Babul. 2012;14(5):20-8.

17. Hodges DM, DeLong JM, Forney CF, Prange RK. Improving the thiobarbituric acid-reactive-substances assay for estimating lipid peroxidation in plant tissues containing anthocyanin and other interfering compounds. Planta. 1999;207(4):604-11. https://doi.org/10.1007/s004250050524

18. Dhindsa RS, Matowe W. Drought tolerance in two mosses: correlated with enzymatic defence against lipid peroxidation. J Exp Bot. 1981;32(1):79-91. https://doi.org/10.1093/jxb/32.1.79

19. Plewa MJ, Smith SR, Wagner ED. Diethyldithiocarbamate suppresses the plant activation of aromatic amines into mutagens by inhibiting tobacco cell peroxidase. Mutat Res. 1991 Mar;247(1):57-64. https://doi.org/10.1016/0027-5107(91)90033-K

20. De Deyn PP, D'Hooge R, Marescau B, Pei YQ. Chemical models of epilepsy with some reference to their applicability in the development of anticonvulsants. Epilepsy Res. 1992 Jul;12(2):87-110. https://doi.org/10.1016/0920-1211(92)90030-W

21. Eraković V, Župan G, Varljen J, Simonić A. Pentylenetetrazol-induced seizures and kindling: changes in free fatty acids, superoxide dismutase, and glutathione peroxidase activity. Neurochem Int. 2003 Jan;42(2):173-8. https://doi.org/10.1016/S0197-0186(02)00070-0

22. Kandratavicius L, Balista PA, Lopes-Aguiar C, Ruggiero RN, Umeoka EH, Garcia-Cairasco N et al. Animal models of epilepsy: use and limitations. Neuropsychiatr Dis Treat. 2014 Sep;10:1693-705. https://doi.org/10.2147/NDT.S50371

23. Uttara B, Singh AV, Zamboni P, Mahajan RT. Oxidative stress and neurodegenerative diseases: a review of upstream and downstream antioxidant therapeutic options. Curr Neuropharmacol. 2009 Mar;7(1):65-74. https://doi.org/10.2174/157015909787602823 
24. Bouayed J, Rammal H, Soulimani R. Oxidative stress and anxiety: relationship and cellular pathways. Oxid Med Cell Longev. 2009 Apr-Jun;2(2):63-7. https://doi.org/10.4161/oxim.2.2.7944

25. Noda Y, Anzai K, Mori A, Kohno M, Shinmei M, Packer L. Hydroxyl and superoxide anion radical scavenging activities of natural source antioxidants using the computerized JES-FR30 ESR spectrometer system. Biochem Mol Biol Int. 1997 Jun;42(1):35-44 https://doi.org/10.1080/15216549700202411

26. Liapi C, Anifandis G, Chinou I, Kourounakis AP, Theodosopoulos S, Galanopoulou P. Antinociceptive properties of 1,8-Cineole and beta-pinene, from the essential oil of Eucalyptus camaldulensis leaves, in rodents. Planta Med. 2007 Oct;73(12):1247-54. https://doi.org/10.1055/s-2007-990224

27. Guimarães AG, Quintans JS, Quintans LJ Jr. Monoterpenes with analgesic activity - a systematic review. Phytother Res. 2013 Jan;27(1):1-15. https://doi.org/10.1002/ptr.4686

28. Kasture VS, Chopde CT, Deshmukh VK. Anticonvulsive activity of Albizzia lebbeck, Hibiscus rosa sinesis and Butea monosperma in experimental animals. J Ethnopharmacol. $2000 \mathrm{Jul} ; 71(1-2): 65-75$. https://doi.org/10.1016/S0378-8741(99)00192-0

29. Gale K. GABA and epilepsy: basic concepts from preclinical research. Epilepsia. 1992;33 Suppl 5:S3-12.

30. Melo MS, Sena LC, Barreto FJ, Bonjardim LR, Almeida JR, Lima JT et al. Antinociceptive effect of citronellal in mice. Pharm Biol. 2010 Apr;48(4):411-6. https://doi.org/10.3109/13880200903150419

31. Quintans-Júnior LJ, Melo MS, Sousa DP, Araújo AA, Onofre AC, Gelain DP et al. Antinociceptive effects of citronellal in formalin-, capsaicin-, and glutamate-induced orofacial nociception in rodents and its action on nerve excitability. J Orofac Pain. 2010;24(3):305-12.

32. Quintans-Júnior LJ, Melo MS, Sousa DP, Araujo AA, Onofre AC, Gelain DP et al. Antinociceptive effects of citronellal in formalin-, capsaicin-, and glutamate-induced orofacial nociception in rodents and its action on nerve excitability. J Orofac Pain. 2010;24(3):305-12. Duplicata da 31
33. Crump FT, Dillman KS, Craig AM. CAMP-dependent protein kinase mediates activity-regulated synaptic targeting of NMDA receptors. J Neurosci. 2001 Jul;21(14):5079-88. https://doi.org/10.1523/JNEUROSCI.21-14-05079.2001

34. Zhu X, Han X, Blendy JA, Porter BE. Decreased CREB levels suppress epilepsy. Neurobiol Dis. 2012 Jan;45(1):253-63. https://doi.org/10.1016/j.nbd.2011.08.009

35. Elisabetsky E, Brum LF, Souza DO. Anticonvulsant properties of linalool in glutamate-related seizure models. Phytomedicine. 1999 May;6(2):107-13. https://doi.org/10.1016/S0944-7113(99)80044-0

36. Sampaio LF, Maia JG, Parijós AM, Souza RZ, Barata LE. Linalool from rosewood (Aniba rosaeodora Ducke) oil inhibits adenylate cyclase in the retina, contributing to understanding its biological activity. Phytother Res. 2012 Jan;26(1):73-7. https://doi.org/10.1002/ptr.3518

37. Gawet S, Wardas M, Niedworok E, Wardas P. Malondialdehyde (MDA) as a lipid peroxidation marker. Wiadomosci lekarskie (Warsaw, Poland: 1960). 2004;57(9-10):453-5.

38. Ho E, Karimi Galougahi K, Liu CC, Bhindi R, Figtree GA. Biological markers of oxidative stress: applications to cardiovascular research and practice. Redox Biol. 2013 Oct;1(1):483-91. https://doi.org/10.1016/j.redox.2013.07.006

39. Azam F, Prasad MV, Thangavel N. Targeting oxidative stress component in the therapeutics of epilepsy. Curr Top Med Chem. 2012;12(9):994-1007. https://doi.org/10.2174/156802612800229224

40. Bast A, Haenen GR, Doelman CJ. Oxidants and antioxidants: state of the art. Am J Med. 1991 Sep;91(3 3C):2S-13S. https://doi.org/10.1016/0002-9343(91)90278-6

41. Ciftci O, Ozdemir I, Tanyildizi S, Yildiz S, Oguzturk H. Antioxidative effects of curcumin, $\beta$-myrcene and 1,8-cineole against 2,3,7,8-tetrachlorodibenzo-p-dioxin-induced oxidative stress in rats liver. Toxicol Ind Health. 2011 Jun;27(5):447-53. https://doi.org/10.1177/0748233710388452 